\title{
Nitrogen balances in farmers fields under alternative uses of a cover crop legume A case study from Nicaragua
}

\author{
Journal Article \\ Author(s): \\ Idupulapati; Frossard, Emmanuel; Oberson, Astrid \\ Publication date: \\ 2010 \\ Permanent link: \\ https://doi.org/10.3929/ethz-b-000021674 \\ Rights / license: \\ In Copyright - Non-Commercial Use Permitted \\ Originally published in: \\ Nutrient Cycling in Agroecosystems 88(3), https://doi.org/10.1007/s10705-010-9368-2
}

Douxchamps, Sabine; Humbert, François-Lionel; Hoek, Rein van der; Mena, Martin; Bernasconi, Stefano M.; Schmidt, Axel; Rao, 


\title{
Nitrogen balances in farmers fields under alternative uses of a cover crop legume: a case study from Nicaragua
}

\author{
Sabine Douxchamps • François-Lionel Humbert • Rein van der Hoek • \\ Martin Mena · Stefano M. Bernasconi • Axel Schmidt • Idupulapati Rao • \\ Emmanuel Frossard $\cdot$ Astrid Oberson
}

Received: 16 October 2009/Accepted: 12 April 2010/Published online: 1 May 2010

(C) Springer Science+Business Media B.V. 2010

\begin{abstract}
Canavalia brasiliensis (canavalia), a drought tolerant legume, was introduced into the smallholder traditional crop-livestock production system of the Nicaraguan hillsides as green manure to improve soil fertility or as forage during the dry season for improving milk production. Since nitrogen $(\mathrm{N})$ is considered the most limiting nutrient for agricultural production in the target area, the objective of this study was to quantify the soil surface $\mathrm{N}$ budgets at plot level in farmers fields over two cropping years for the traditional maize/bean rotation and the alternative maize/canavalia rotation. Mineral
\end{abstract}

S. Douxchamps $(\bowtie) \cdot$ F.-L. Humbert .

E. Frossard · A. Oberson

ETH Zurich, Institute of Plant, Animal and

Agroecosystem Sciences, Eschikon 33, 8315 Lindau,

Switzerland

e-mail: sabinedouxchamps@yahoo.com

R. van der Hoek · A. Schmidt

Centro Internacional de Agricultura Tropical (CIAT),

Managua, Nicaragua

M. Mena

Instituto Nicaraguense de Tecnología Agropecuaria

(INTA), Managua, Nicaragua

S. M. Bernasconi

ETH Zurich, Geological Institute, Zurich, Switzerland

I. Rao

Centro Internacional de Agricultura Tropical (CIAT),

Cali, Colombia fertilizer $\mathrm{N}$, seed $\mathrm{N}$ and symbiotically fixed $\mathrm{N}$ were summed up as $\mathrm{N}$ input to the system. Symbiotic $\mathrm{N}_{2}$ fixation was assessed using the ${ }^{15} \mathrm{~N}$ natural abundance method. Nitrogen output was quantified as $\mathrm{N}$ export via harvested products. Canavalia derived in average $69 \%$ of its $\mathrm{N}$ from the atmosphere. The amount of $\mathrm{N}$ fixed per hectare varied highly according to the biomass production, which ranged from 0 to $5,700 \mathrm{~kg} \mathrm{ha}^{-1}$. When used as green manure, canavalia increased the $\mathrm{N}$ balance of the maize/canavalia rotation but had no effect on the $\mathrm{N}$ uptake of the following maize crop. When used as forage, it bears the risk of a soil $\mathrm{N}$ depletion up to $41 \mathrm{~kg} \mathrm{~N} \mathrm{ha}^{-1}$ unless $\mathrm{N}$ would be recycled to the plot by animal manure. Without $\mathrm{N}$ mineral fertilizer application, the $\mathrm{N}$ budget remains negative even if canavalia was used as green manure. Therefore, the replenishment of soil $\mathrm{N}$ stocks by using canavalia may need a few years, during which the application of mineral $\mathrm{N}$ fertilizer needs to be maintained to sustain agricultural production.

Keywords ${ }^{15} \mathrm{~N}$ natural abundance method . Canavalia brasiliensis . Forage legume . Nicaraguan hillsides · Nitrogen budget . On-farm trials

$\begin{array}{ll}\text { Abbreviations } \\ \text { BG } & \text { Bean grain } \\ \text { BP } & \text { Bean plant } \\ \text { CB } & \text { Canavalia above-ground biomass }\end{array}$




\begin{tabular}{|c|c|}
\hline CBR & Canavalia biomass removed \\
\hline$\delta^{15} \mathrm{~N}$ & ${ }^{15} \mathrm{~N}$ natural abundance signature (\%o) \\
\hline $\mathrm{M} / \mathrm{B}$ & Maize-bean \\
\hline $\mathrm{M} / \mathrm{C}$ & Maize-canavalia \\
\hline $\mathrm{M} / \mathrm{CX}$ & $\begin{array}{l}\text { Maize-canavalia with } \mathrm{X} \% \text { of canavalia } \\
\text { biomass removed }\end{array}$ \\
\hline MG & Maize grain \\
\hline MDG & Maize damaged grain \\
\hline $\mathrm{MC}$ & Maize cob \\
\hline MH & Maize husk \\
\hline MRE & Maize recycled ears \\
\hline MR & Maize residues (stalks and leaves) \\
\hline $\mathrm{N}$ & Nitrogen \\
\hline$\%$ Ndfa & $\begin{array}{l}\text { Rate of nitrogen derived from the } \\
\text { atmosphere }\end{array}$ \\
\hline Nfert & $\begin{array}{l}\text { Amount of nitrogen applied with mineral } \\
\text { fertilizers }\left(\mathrm{kg} \mathrm{ha}^{-1}\right)\end{array}$ \\
\hline Nfix & Amount of nitrogen fixed $\left(\mathrm{kg} \mathrm{ha}^{-1}\right)$ \\
\hline Nseed & $\begin{array}{l}\text { Amount of nitrogen supplied through seeds } \\
\left(\mathrm{kg} \mathrm{ha}^{-1}\right) \text { at the time of sowing }\end{array}$ \\
\hline $\mathrm{N}_{\mathrm{X}}$ & $\begin{array}{l}\text { Amount of nitrogen in the plant part } \mathrm{X} \\
\left(\mathrm{kg} \mathrm{ha}^{-1}\right)\end{array}$ \\
\hline
\end{tabular}

\section{Introduction}

Population growth in the rural poor areas of developing countries has contributed to land use intensification that adversely affects soil fertility, with nutrient depletion and soil erosion being major causes of soil degradation (Tan et al. 2005). Crop and livestock productivity therefore declines, causing decreased income generation opportunities, and food insecurity. In the Nicaraguan hillsides, population is expanding at an annual growth rate of $1.3 \%$ (IFAD 2009). Cropping is limited to two short and successive rainy seasons, and therefore livestock suffers forage shortage during the long dry season of 5-6 months. Smallholders are mostly affected by the declined soil fertility due to their marginalized situation and their inability to overcome production constraints (Pfister 2003). Agricultural production usually does not exceed the needs for subsistence, making the sale of products almost impossible. Sufficient amounts of mineral fertilizers are not affordable and in small-scale farms, nitrogen $(\mathrm{N})$ depletion is a major production constraint (Ayarza et al. 2007; Smyth et al. 2004).
Introduction of cover crop legumes can be beneficial to such a system due to their ability to add $\mathrm{N}$ via symbiotic $\mathrm{N}_{2}$ fixation (Boddey et al. 1997; Ojiem et al. 2007) and to provide surface mulch during the dry season or to provide fodder to livestock (Said and Tolera 1993). In order to identify the most suitable legume for the Nicaraguan hillsides, forage specialists and local extentionists induced farmer participatory evaluation of potential legume species. Among all the legumes tested, Canavalia brasiliensis Mart. Ex. Benth (canavalia), also known as Brazilian jack bean, attracted most attention from farmers mainly due to its vigorous growth, good soil cover and outstanding level of adaptation to drought stress based on green forage yield. Moreover, canavalia is also adapted to a wide range of other stress factors, including low fertility soils (CIAT 2004; Schloen et al. 2005; Schmidt et al. 2005).

Previous studies have indeed shown positive effects of canavalia on crop productivity when integrated in the crop rotation (Bordin et al. 2003). Maize yield was higher after a rotation with canavalia than after other cover crops, because of its high biomass production and rapid litter decomposition rate (de Carvalho et al. 2008). In an on-station study over 4-years, the use of canavalia green manure in rotation with maize was equivalent to a replacement of $50 \mathrm{~kg} \mathrm{~N} \mathrm{ha}^{-1}$ of mineral $\mathrm{N}$ fertilizer (Burle et al. 1999). Canavalia brasiliensis is known to nodulate well (Alvarenga et al. 1995) but its contribution through symbiotic $\mathrm{N}_{2}$ fixation has not been quantified. The integration of a highly productive legume crop in a cropping system could also increase mining of nutrients (Bünemann et al. 2004), and a yield increase of the subsequent crop also means higher $\mathrm{N}$ export via harvested products. The contribution of a legume to a system may also be further diminished if crop residues are used as fodder (Peoples and Craswell 1992). Before promoting the use of canavalia to smallholders, it is important to evaluate whether canavalia results in a net $\mathrm{N}$ input to the cropping system, i.e., whether the $\mathrm{N}$ input through symbiotic $\mathrm{N}_{2}$ fixation exceeds $\mathrm{N}$ output through harvest. Such imbalances can be revealed by calculating the $\mathrm{N}$ budgets for the rotations of interest. Nutrient budgets are commonly used as indicators of changes in soil fertility at national or regional scale (Bindraban et al. 2000; Smaling et al. 1993), and more recently have been useful to evaluate soil 
fertility status and nutrient efficiency of African smallholder crop-livestock systems (Rufino et al. 2009; Zingore et al. 2007). However, there is no published information on on-farm $\mathrm{N}$ budgets on the alternative uses of forage legumes in Central America. We chose the soil surface budget approach where all the $\mathrm{N}$ entering the soil via soil surface and leaving the soil via crop uptake are recorded (Adu-Gyamfi et al. 2007; Oenema et al. 2003; Watson et al. 2002).

Canavalia was tested either as green manure to improve soil fertility or as forage to improve milk production. When used as green manure, it was left on the plot during the whole dry season and was incorporated at the onset of the next rainy season before sowing maize. As forage, it was cut and removed at the beginning of the dry season to simulate grazing. The use of the traditional maize/ bean $(\mathrm{M} / \mathrm{B})$ rotation as control does not mean that canavalia should replace bean. Indeed, farmers grow bean on only half of the cultivated area. Thus there is possibility to grow canavalia on the other half, and to alternate each year between the areas under maize/ canavalia $(\mathrm{M} / \mathrm{C})$ and $\mathrm{M} / \mathrm{B}$ rotations.

The main objective of this study was to quantify the soil surface $\mathrm{N}$ budgets at plot level in farmers fields over two cropping years for the traditional M/B rotation and the alternative $\mathrm{M} / \mathrm{C}$ rotation. We tested the hypothesis that the introduction of canavalia into the traditional rotation will help reversing soil $\mathrm{N}$ depletion by (1) fixing a high proportion of $\mathrm{N}$, (2) increasing the $\mathrm{N}$ budget of the crop rotation, and (3) thereby increasing maize yields the year following its integration into the production system. We emphasized $\mathrm{N}$ output via crop harvest and $\mathrm{N}$ input via $\mathrm{N}_{2}$ fixation of canavalia and bean. We also assessed $\mathrm{N}$ recycled with crop residues.

\section{Materials and methods}

Study area and farmer practices

The study area is located in the hillsides of northern Nicaragua, in the Rio Pire watershed (Municipality of Condega, Department of Esteli), within a $2 \mathrm{~km}$ radius around the community of Santa Teresa $\left(13^{\circ} 18^{\prime} \mathrm{N}\right.$, $86^{\circ} 26^{\prime} \mathrm{W}$ ) (Fig. 1). Soils are classified as Udic and Pachic Argiustolls (MAGFOR 2008). The climate is classified as tropical savannah (Aw) according to the

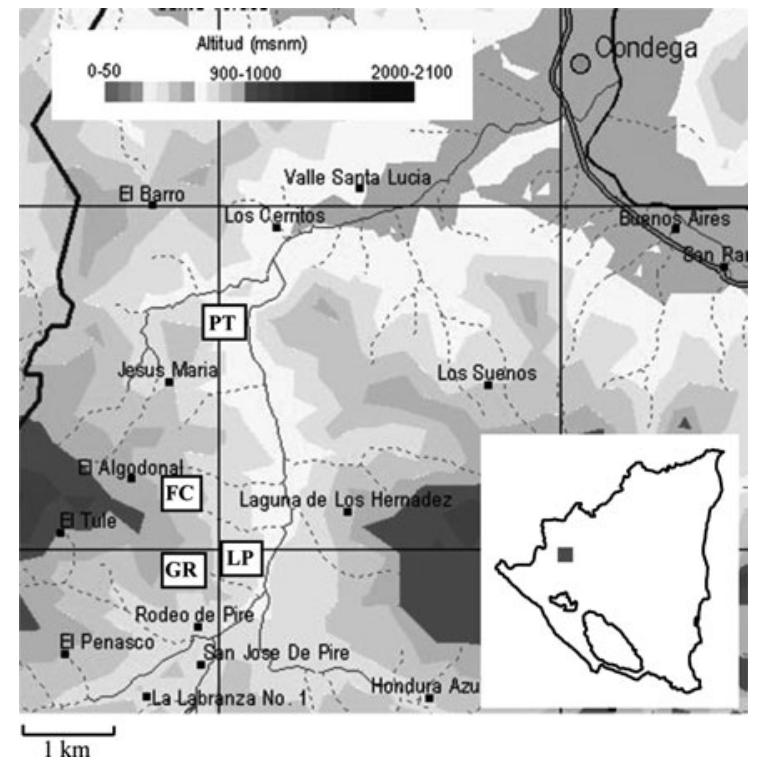

Fig. 1 Location of the sites in the Rio Pire watershed (source: INETER). The map inserted at the bottom right depicts Nicaragua, the grey square being the study area

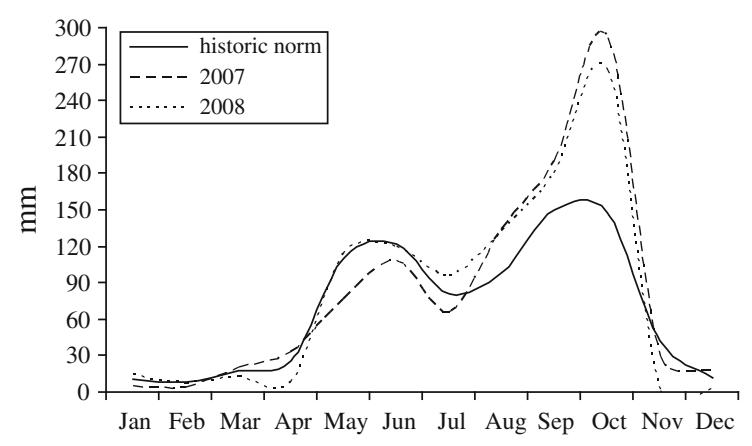

Fig. 2 Monthly rainfall distribution during the 2 years of the study with the historical normal value for the region (mean monthly precipitations since 1977), measured at the meteorological station of Condega (source: INETER 2009)

Köppen-Geiger classification (Peel et al. 2007). Annual mean rainfall is $825 \mathrm{~mm}$ (INETER 2009) and has a bimodal distribution pattern (Fig. 2).

Farmers are traditional crop-livestock smallholders, cultivating maize and bean on about 2 ha of land, and sharing an area for grazing on less productive pastures based on Jaragua grass (Hyperrenia rufa). Cultivation is done essentially with hand-held tools. Prior to sowing maize land is usually prepared with a plough pulled by oxen if accessibility to the field and slopes allow; otherwise it is prepared manually using a hoe. Maize is sown at the end of May, at the onset 
Table 1 Selected properties of the four study sites

\begin{tabular}{lllllllll}
\hline Site & Altitude masl & Situation & Slope range $\%$ & Texture & $\mathrm{pH}$ & Total $\mathrm{C}^{\mathrm{a}} \mathrm{g} / \mathrm{kg}$ & Total $\mathrm{N}^{\mathrm{b}} \mathrm{g} / \mathrm{kg}$ & Available $\mathrm{P}^{\mathrm{c}} \mathrm{mg} / \mathrm{kg}$ \\
\hline FC & 706 & Hill & $3-17$ & Clay & $6.4(0.1)$ & $25.2(2.4)$ & $1.90(0.15)$ & $10.1(3.5)$ \\
$\mathrm{GR}$ & 707 & Hill & $7-34$ & Sandy loam & $6.3(0.4)$ & $10.9(4.0)$ & $1.02(0.34)$ & $14.7(6.6)$ \\
LP & 674 & Valley & $1-5$ & Clay loam & $6.2(0.3)$ & $21.8(0.9)$ & $1.57(0.06)$ & $75.5(7.2)$ \\
PT & 651 & Valley & $0-3$ & Sandy clay loam & $6.7(0.3)$ & $14.8(1.4)$ & $1.13(0.10)$ & $41.9(6.0)$ \\
\hline
\end{tabular}

Sites are named after farmer's initials. For soil chemical properties: averages on all plots $(0-10 \mathrm{~cm}$ depth $)$, with standard deviation in parenthesis $(n=15)$

a Measured following Nelson and Sommers (1982)

b Measured following Krom (1980)

c Measured with anion-exchange resins (Tiessen and Moir 1993)

of the first rainy season. Maize is fertilized with urea and sometimes also with NPK fertilizer. At maturity, plants are cut above the ears and maize ears are left drying on the stalks for 2-3 months. Meanwhile, beans are sown around mid-September between the maize rows to take advantage of the part of the bimodal rainfall pattern. Both maize and beans are harvested in December. In January, at the beginning of the dry season, forage is getting scarce in the grazing area, and farmers let their cows enter the cultivated fields to graze crop residues.

System treatments and experimental design

Four farmers of Santa Teresa, who were interested in integrating canavalia in a part of their production area, were identified. They chose themselves the site for the experiment within their farm. Crop management was done by the farmers, whereas data and samples were collected by the scientists. Sites are named after farmer's initials: FC (Felipe Calderón), GR (Gabriel Ruiz), LP (Lorenzo Peralta) and PT (Pedro Torres). General site characteristics are given in Table 1.

On each site five crop rotations were established on 70-100 $\mathrm{m}^{2}$-plots, and repeated in three completely randomized blocks, for a total of 60 plots. The control treatment was the traditional $\mathrm{M} / \mathrm{B}$ rotation. The four others were $\mathrm{M} / \mathrm{C}$ rotations with four different cutting intensities to simulate grazing, i.e. with $0 \%(\mathrm{M} / \mathrm{C} 0)$, $50 \%(\mathrm{M} / \mathrm{C} 50), 75 \%(\mathrm{M} / \mathrm{C} 75)$ or $100 \%(\mathrm{M} / \mathrm{C} 100)$ removal of canavalia biomass (Fig. 3). Land was prepared according to the usual practice, with hoe on FC site and ploughing with oxen on the other sites. Farmers sowed maize (Zea mays var. Catacamas) at the end of May 2007, by hand, with a seeding rate of
$23 \mathrm{~kg}$ per hectare, with a row-to-row spacing of $75 \mathrm{~cm}$ and a plant-to-plant spacing of $50 \mathrm{~cm}$. Compound NPK fertilizer (12-30-10) and urea were applied 8 and 22 days after sowing respectively. The doses varied from 0 to $8 \mathrm{~kg} \mathrm{~N}^{-1}$ for NPK complex and from 30 to $60 \mathrm{~kg} \mathrm{~N} \mathrm{ha}^{-1}$ for urea, according to each farmer's usual practices (Table 2). Weed control was done before maize germination by spraying glyphosate and after germination manually with a large knife. Cypermethrin ${ }^{1}$ was used for insect control. Bean (Phaseolus vulgaris var. INTA seda rojo) or canavalia (var. CIAT17009) were sown between maize rows at the end of September with a seeding rate of 78 and $51 \mathrm{~kg}$ per hectare, respectively. No fertilizer was applied to either legume crop. Maize and bean harvest occurred between November and December according to the usual practice. In January, the different percentages of canavalia above ground biomass were removed from the field. In May 2008, remaining standing maize stalks and canavalia plants were cut with large knife and left on the ground as mulch. Fields in 2008 were prepared as described for 2007, using either plough or hoe, and treatments were repeated on the same plots. Farmers did not reduce mineral fertilizer application after the first canavalia rotation.

Precipitation during crop growth (May to January), measured at the meteorological station of the nearby municipality Condega, was similar for both years (about $920 \mathrm{~mm}$ ), which is $19 \%$ above the normal rainfall (Fig. 2). Temperature for both years was also similar, with a mean of $24^{\circ} \mathrm{C}$, a maximum of $33^{\circ} \mathrm{C}$ and a minimum of $16^{\circ} \mathrm{C}$ (INETER 2009).

\footnotetext{
1 (RS)-Cyano-3-phenoxybenzyl-2,2-dimethyl-3-(2,2-dichlorvinyl)-cyclopropan-1-carboxylat.
} 


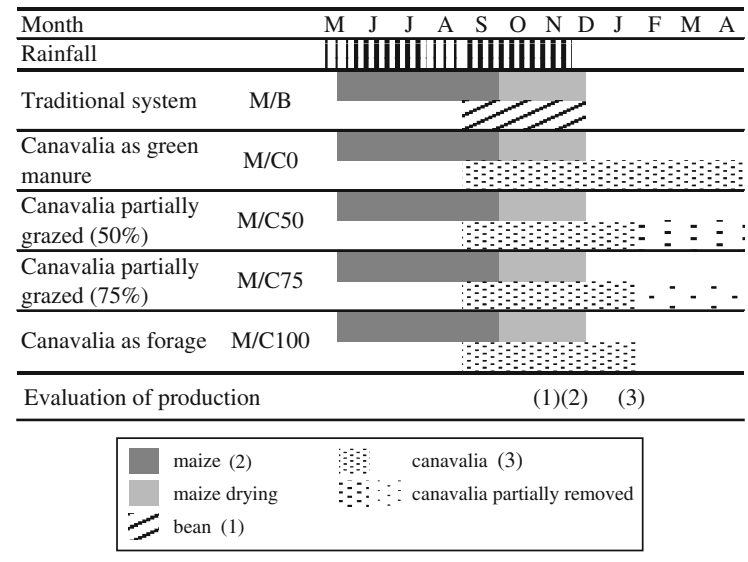

Fig. 3 Treatments replicated three times on each site: the traditional maize/bean rotation and the tested maize/canavalia rotation (part 2) with different cutting intensities of canavalia during the dry season, to simulate grazing

Symbiotic $\mathrm{N}_{2}$ fixation

The rates of $\mathrm{N}$ derived from the atmosphere ( $\% \mathrm{Ndfa})$ in canavalia and bean were assessed both years using the ${ }^{15} \mathrm{~N}$ natural abundance method (Shearer and Kohl 1986), which is based on the slight natural differences between the ${ }^{15} \mathrm{~N}$ abundance of the soil and the ${ }^{15} \mathrm{~N}$ abundance of the atmosphere. As reference plants, non-fixing dicotyledonous weeds (Oberson et al. 2007) growing at the same time as the legumes have been selected and marked in the field to avoid them being cut during weed control by the farmers. Other herbaceous and shrubby weeds were excluded. Two weeds were chosen in the immediate proximity (i.e. within a radius of $50 \mathrm{~cm}$ ) of each marked legume. Weeds were limited to four different species per site and per year, each of them being present at least five times for each legume and as well distributed as possible across the site. Species chosen were Baltimora recta, Delilia biflora, Euphorbia graminea, Euphorbia hirta, Lagascea mollis, Melanthera aspera, Mitrocarpus hirtus, Richardia scabra, Borreria suaveolens, Ageratum conyzoides, and Conyza Canadensis (Table 2). Sampling of canavalia occurred 3 months after planting, before drought, at the beginning of the flowering period. For bean, sampling occurred at the growth stage of late flowering to early pod filling. Five bean plants and five canavalia plants were harvested per block, together with their paired weeds, resulting in thirty legumes and sixty reference plants per site and per year. Table 2 shows slightly lower sample numbers, as in a few cases the marked plant did not develop well and was therefore not harvested. Plants were dried and analyzed for their ${ }^{15} \mathrm{~N}$ abundance (see below).

The \%Ndfa for each legume plant was calculated following Shearer and Kohl (1986), using its two paired weeds as references. The final $\% \mathrm{Ndfa}$ per legume and per site was then calculated as the average of the fifteen \% Ndfa estimated from single legume plants for this site.

Table 2 Average $\delta^{15} \mathrm{~N}$ of the reference plants and the legumes for each site, year 2007 and 2008 grouped

\begin{tabular}{|c|c|c|c|c|c|c|c|c|}
\hline \multirow[t]{2}{*}{ Species } & \multicolumn{2}{|l|}{$\mathrm{FC}$} & \multicolumn{2}{|c|}{ GR } & \multicolumn{2}{|l|}{ LP } & \multicolumn{2}{|l|}{ PT } \\
\hline & $n$ & $\delta^{15} \mathrm{~N}$ & $n$ & $\delta^{15} \mathrm{~N}$ & $n$ & $\delta^{15} \mathrm{~N}$ & $n$ & $\delta^{15} \mathrm{~N}$ \\
\hline Ageratum conyzoides & 5 & $3.52(0.63)$ & & & & & & \\
\hline Baltimora recta & & & & & 55 & $3.69(0.81)$ & & \\
\hline Borreria suaveolens & 30 & $3.67(0.43)$ & & & & & & \\
\hline Conyza canadensis & & & 5 & $3.11(0.59)$ & & & & \\
\hline Delilia biflora & 41 & $4.53(0.87)$ & & & & & & \\
\hline Euphorbia graminea & & & & & & & 15 & $3.36(1.21)$ \\
\hline Euphorbia hirta & 19 & $3.88(0.65)$ & 6 & $2.83(0.54)$ & & & 32 & $4.41(1.43)$ \\
\hline Lagascea mollis & & & & & & & 35 & $5.87(2.06)$ \\
\hline Melanthera aspera & & & 42 & $5.02(2.26)$ & & & 5 & $5.88(1.18)$ \\
\hline Mitrocarpus hirtus & 24 & $3.64(0.61)$ & 43 & $3.68(1.99)$ & 54 & $3.24(0.61)$ & 24 & $5.19(0.81)$ \\
\hline Richardia scabra & & & 16 & $5.20(1.91)$ & & & 9 & $6.23(0.88)$ \\
\hline Bean & 30 & $-0.12(0.81)$ & 26 & $-0.16(1.05)$ & 25 & $-0.91(0.67)$ & 30 & $0.60(1.13)$ \\
\hline Canavalia & 29 & $-0.02(0.64)$ & 29 & $0.32(0.92)$ & 29 & $0.20(0.57)$ & 28 & $1.04(1.08)$ \\
\hline
\end{tabular}

Standard deviation is given in parenthesis 
The $B$-value, i.e. the isotopic fractionation during $\mathrm{N}_{2}$ fixation, was obtained from a pot experiment in the greenhouse at the International Centre of Tropical Agriculture (CIAT), Colombia ( $3^{\circ} 30^{\prime} \mathrm{N}, 76^{\circ} 21^{\prime} \mathrm{W}$ ), following the procedure of Unkovich et al. (1994). Plants were grown from the end of November 2007 to the end of February 2008. Temperature in the greenhouse fluctuated from $20^{\circ}$ to $37^{\circ} \mathrm{C}$ in synchrony with photoperiod, and relative humidity ranged from 40 to $90 \%$. Eighteen 3.3 1-pots were filled with washed white quartz, planted with canavalia or bean and watered daily with an $\mathrm{N}$-free nutrient solution. The inoculum used was made from a mixture of soils from our study sites. Harvest occurred at the same development stage as in the field. Shoot $\delta^{15} \mathrm{~N}$ values were corrected for seed $\mathrm{N}$ effect using a mass balance (Boddey et al. 2000; Hogberg et al. 1994) accounting for the $\mathrm{N}$ distribution between shoots and roots.

Evaluation and fate of crop production

\section{Maize}

Maize production was evaluated in each of the 60 plots of the experiment. To evaluate the yield of the different maize parts, several row segments were chosen to represent the plot, excluding the border lines, and equivalent to 20-30 m-row length in total per plot. On these row segments, plants were counted and classified into two categories: plants with harvestable ears and plants without. Harvestable ears were considered good for human consumption by the farmers. The category "plants without harvestable ear" included plants that were without ear, with damaged ear, with already harvested ear, or with ear on the ground. Samples of ears of each category, corresponding to the number of ears for $2 \mathrm{~m}^{2}$, were taken in each plot.

Harvestable ears were separated after sampling into good grain, bad grain, cobs, and husks. Samples were pooled per block, except for good grain, for which samples were kept separated per plot. Yield of the different ear parts was assessed as follow: where no. of harvestable ears per plot correspond to the number of plants with harvestable ears per plot, as almost no plants developed more than one ear.

Samples of not harvestable ears were not separated into plant parts because their state did not allow doing so. The amount of not harvested ears per hectare was calculated as in formula [1], except that the number and weight of not harvested ears were used.

Samples of stalks and leaves were taken to complete maize biomass production estimation. As traditionally farmers cut the upper part of the stalks to let the cob dry, only a few entire plants could be found and sampled on two sites. Assuming that average stalk and leaf weight was the same on all plots, yields were calculated as in formula [1] using the total number of plants per plot.

In order to know which plant parts are exported and which are recycled on the plot, the fate of maize harvested ears was determined by plant part for each farmer. Maize grains (MG) were exported from the plot for human consumption, maize cobs (MC) and damaged grains (MDG) (i.e. broken, discoloured, shrivelled or undersized grains) were exported to be fed to pigs or used for combustible, maize husks $(\mathrm{MH})$ were either recycled on the plot or exported to be fed to cows. Maize without harvestable ears (MRE) and residues (stalks and leaves) (MR) were not removed from the plot.

\section{Bean}

Bean yields were assessed according to farmer's current practice. On $1 \mathrm{~m}^{2}$ in each plot, bean plants were removed from the soil with their roots, separated into grain (BG) and residues (shoot and root, BP), and both plant parts were sampled and weighed separately. The fate of BG is usually to be exported for consumption, while BP remains on the plots. However, during both years of this study, heavy rainfall over short periods and to larger extent diseases such as angular leaf spot killed many bean plants leading to very low yields. Farmers harvested only when expected grain value compensated labour cost for harvest.

Yield $_{\text {ear part }}\left[\mathrm{kg} \mathrm{ha}^{-1}\right]=\frac{\text { no.harvestable earsper plot } \times \text { weight }_{\text {ear part }}\left[\mathrm{kg} \mathrm{ear}^{-1}\right]}{\text { area plot }\left[\mathrm{m}^{2}\right]} \times 10,000$ 


\section{Canavalia}

At each canavalia cutting time, above-ground biomass (CB) production was assessed in each plot with the Comparative Yield Method (Haydock and Shaw 1975) in which the yields of random $1 \mathrm{~m}^{2}$-quadrants are rated with respect to a set of five reference quadrants preselected to provide a scale covering the range of biomass encountered within each plot. Ten quadrants were rated per plot. Different proportions-100, 75, 50 or $0 \%$ - of the available biomass were removed according to the experimental plan, by cutting canavalia with large knifes either on a plant number basis, or on a height basis when plants were undistinguishable. The M/C100 plots, where all the biomass was removed and weighed, were used as control of the biomass estimate obtained with the Comparative Yield Method. Samples of the above ground biomass were taken from each block. Removed biomass (CBR) was exported from the plot to be fed to animals.

\section{Plant analysis}

Canavalia, bean and reference plants sampled in the field were dried in a wooden oven at about $40^{\circ} \mathrm{C}$ until constant dry weight and ground with a rotary knife mill at CIAT-Nicaragua. Maize plant parts were dried at ambient temperature and ground with the same mill. Canavalia and bean samples from the greenhouse were dried at $70^{\circ} \mathrm{C}$ and ground with a rotary knife mill at CIAT-Colombia.

All samples were then shipped to Switzerland, powdered with a ball mill (Retsch, GmbH, Germany) and analyzed for total $\mathrm{N}$ on a Thermo Electron FlashEA 1112 Automatic Elemental Analyzer. The $\delta^{15} \mathrm{~N}$ of legumes and reference plants were measured at the Geological Institute of the ETH Zurich on a Thermo Electron FlashEA 1112 coupled in continuous-flow with a Thermo-Fisher MAT 253 mass spectrometer. Finely ground field pea seed with an atom $\%{ }^{15} \mathrm{~N}$ of 0.367 was used as analytical standard.

\section{Soil surface $\mathrm{N}$ budgets}

Soil surface $\mathrm{N}$ budgets were estimated for all plots and for both years (May to January) following the equation:
$\mathrm{N}$ budget $\left[\mathrm{kg} \mathrm{N} \mathrm{ha}^{-1}\right]=\mathrm{N}$ input $-\mathrm{N}$ output

$$
\begin{aligned}
= & (\text { Nfix }+ \text { Nfert }+ \text { Nseed }) \\
& -(\text { Nexport })
\end{aligned}
$$

where Nfix is the contribution of symbiotic $\mathrm{N}_{2}$ fixation, Nfert is the mineral fertilization, Nseed accounts for maize, bean and canavalia seeds and Nexport is the amount of $\mathrm{N}$ exported from the plot.

Nfix was calculated as the product of $\% \mathrm{Ndfa}, \mathrm{N}$ concentration and legume biomass. Nfert was calculated for each site based on the amount of fertilizer applied by the farmer and the $\mathrm{N}$ concentration in urea and NPK complex. Nseed was calculated as the product of $\mathrm{N}$ concentration and seed density.

Nexport from the plot differed for each site according to the fate given by each farmer to the different plant parts of the crops and was estimated as:

$\begin{aligned} \text { Nexport }\left[\mathrm{kg} \mathrm{N} \mathrm{ha}^{-1}\right]= & \mathrm{N}_{\mathrm{MG}}+\mathrm{N}_{\mathrm{MDG}}+\mathrm{N}_{\mathrm{MC}} \\ & +\mathrm{N}_{\mathrm{MH}}+\mathrm{N}_{\mathrm{BG}}+\mathrm{N}_{\mathrm{CBR}}\end{aligned}$

where $\mathrm{N}_{X}$ is the amount of $\mathrm{N}$ in $\mathrm{kg} \mathrm{ha}^{-1}$ in each of the mentioned plant part $\mathrm{X}$, obtained from its $\mathrm{N}$ concentration multiplied by its biomass production in $\mathrm{kg} \mathrm{ha}^{-1}$ (dry matter basis).

$\mathrm{N}_{\mathrm{MH}}$ equals 0 if the farmer left the husks on the plot. $\mathrm{N}_{\mathrm{BG}}$ equals 0 if the farmer decided to not harvest beans, or in $\mathrm{M} / \mathrm{C}$ rotations. $\mathrm{N}_{\mathrm{CBR}}$ equals 0 in $\mathrm{M} / \mathrm{B}$ and $\mathrm{M} / \mathrm{C} 0$ rotations.

Nitrogen recycled with crop residues

The amount of $\mathrm{N}$ recycled on each plot is the amount of $\mathrm{N}$ in crop residues and in remaining canavalia, calculated as follows:

$$
\begin{aligned}
\text { Nrecycled }\left[\mathrm{kg} \mathrm{N} \mathrm{ha}^{-1}\right]= & \mathrm{N}_{\mathrm{MR}}+\mathrm{N}_{\mathrm{BP}}+\mathrm{N}_{(\mathrm{CB}-\mathrm{CBR})} \\
& +\mathrm{N}_{\mathrm{MH}}+\mathrm{N}_{\mathrm{BG}}+\mathrm{N}_{\mathrm{MRE}}
\end{aligned}
$$

where $\mathrm{N}_{\mathrm{X}}$ is the amount of $\mathrm{N}$ in $\mathrm{kg} \mathrm{ha}^{-1}$ in each of the mentioned plant material $\mathrm{X}$, obtained from its $\mathrm{N}$ concentration multiplied by its biomass production in $\mathrm{kg} \mathrm{ha}^{-1}$.

$\mathrm{N}_{\mathrm{MH}}$ equals 0 if the farmer exports the husks. $\mathrm{N}_{\mathrm{BG}}$ equals 0 if the farmer decided to harvest beans, or in $\mathrm{M} / \mathrm{C}$ rotations. $\mathrm{N}_{(\mathrm{CB}-\mathrm{CBR})}$ equals 0 in $\mathrm{M} / \mathrm{B}$ and $\mathrm{M} /$ C100 rotations. 
Data analysis

Statistical analyses were performed using the program R (R Development Core Team, 2007). Rightskewed variables were log-transformed before the analysis. Yields were submitted to a Wilcoxon's rank-sum test to check for significant differences between the 2 years. The significance of the effects of site and treatment on crop production and on $\mathrm{N}$ balance was tested by an analysis of variance using aov and lme functions in $\mathrm{R}$ (Pinheiro and Bates 2000). The model was composed by treatment as fixed factor, site and bloc as random factors, bloc being nested within site.

\section{Results}

$\mathrm{N}$ inputs: symbiotic $\mathrm{N}_{2}$ fixation

The $B$-values obtained from the greenhouse experiment were $-1.26 \%$ for canavalia and $-3.74 \%$ for bean. The $\delta^{15} \mathrm{~N}$ of the reference plants ranged from 0.2 to $13.1 \%$ in 2007 and from 0.5 and $8.4 \%$ in 2008 . Table 2 presents the average $\delta^{15} \mathrm{~N}$ per species and per site, for both years together as there was no significant difference between the 2 years. The $\delta^{15} \mathrm{~N}$ of the legumes ranged from -2 to $2 \%$, with extreme values up to $4.6 \%$ in 2007 and $2.6 \%$ in 2008 . Each legume had significantly lower $\delta^{15} \mathrm{~N}$ than its two reference plants. Figure 4 shows the $\delta^{15} \mathrm{~N}$ of each $\mathrm{N}_{2}$-fixing plant and the mean $\delta^{15} \mathrm{~N}$ of its paired reference plants for all sites in 2007 and in 2008. Average \% Ndfa was 55 and $58 \%$ for bean, and 64 and $74 \%$ for canavalia in 2007 and 2008, respectively. Among sites, mean $\%$ Ndfa did not vary much, with a standard deviation of $3-9 \%$. For bean, average Ndfa did not differ significantly between 2007 and $2008(P=0.478)$. For canavalia, average Ndfa in 2008 was significantly $(P=0.000)$ higher than in 2007.

$\mathrm{N}$ outputs: crop production

Maize

Maize grain yields (Fig. 5) conformed to the usual production of the region (personal communication from the farmers), with an average yield of $2,410 \mathrm{~kg} \mathrm{ha}^{-1}$ in 2007 and $2,070 \mathrm{~kg} \mathrm{ha}^{-1}$ in 2008.
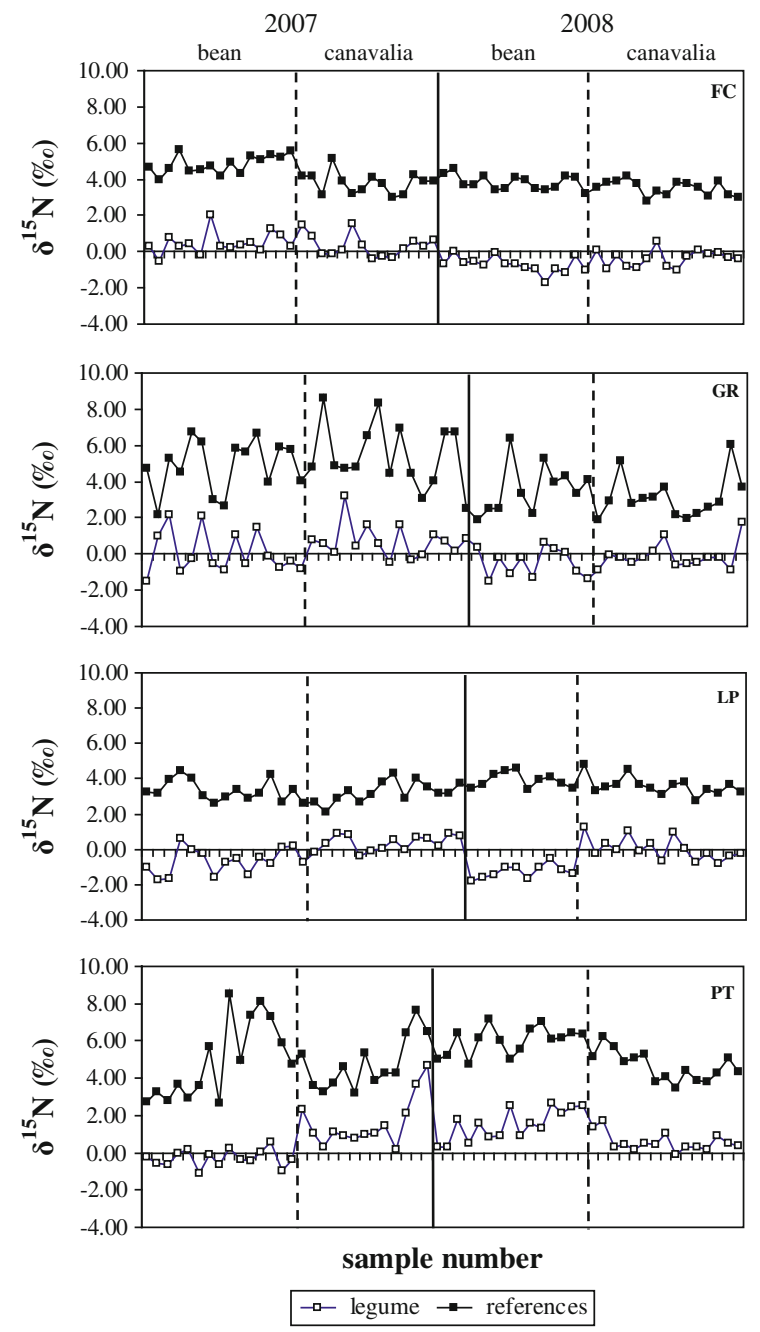

Fig. 4 Delta ${ }^{15} \mathrm{~N}$ of individual legumes and mean $\delta^{15} \mathrm{~N}$ of their paired references on all sites in 2007 and 2008. The position of the vertical line between years and between legumes varies for each site according to the number of samples analyzed

Grain yields were not significantly different between the 2 years $(P=0.107)$. The first year of rotation made no effect on grain yields of the subsequent year $(P=0.187)$. Yields were affected significantly by the site in $2008(P=0.025)$ but not in $2007(P=0.135)$.

\section{Bean}

Bean grain production (Fig. 5) was much lower for both years compared with the farmer reported mean production value of $1300 \mathrm{~kg} \mathrm{ha}^{-1}$. This was mainly due to heavy rains and diseases. The grain yield ranged 13 to $320 \mathrm{~kg} \mathrm{ha}^{-1}$ in 2007 and from 0 to 

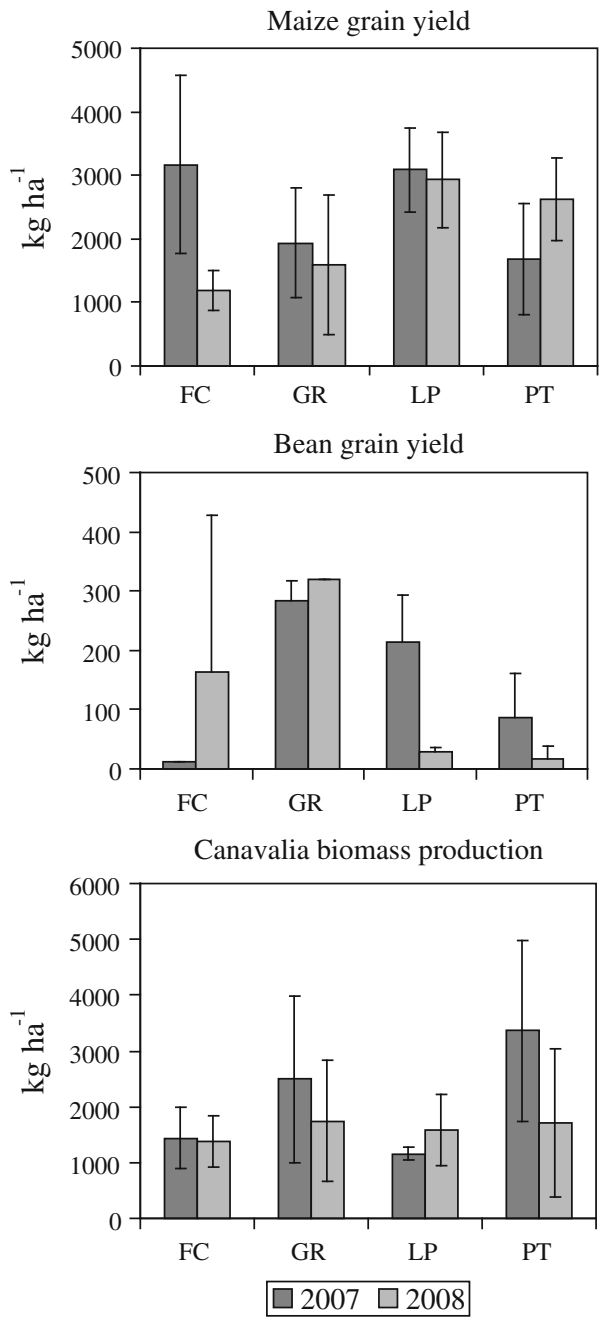

Fig. 5 Maize grain production $(n=15)$, bean grain production $(n=3)$ and canavalia biomass production $(n=12)$. Error bars represent the standard deviation

$470 \mathrm{~kg} \mathrm{ha}^{-1}$ in 2008. Yields were not significantly different between 2007 and $2008(P=0.832)$.

\section{Canavalia}

Canavalia biomass production (Fig. 5) varied between 0 and $5,700 \mathrm{~kg} \mathrm{ha}^{-1}$, with a mean value of $2,110 \mathrm{~kg} \mathrm{ha}^{-1}$ in 2007 . In 2008, the biomass production varied between 290 and $4,330 \mathrm{~kg} \mathrm{ha}^{-1}$, with a mean value of $1,530 \mathrm{~kg} \mathrm{ha}^{-1}$. Biomass did not significantly differ between both years $(P=0.223)$ and was not influenced by the site neither in 2007 $(P=0.070)$ nor in $2008(P=0.999)$. The removal of canavalia biomass at the beginning of the dry season in 2007 had no significant effect on the production in $2008(P=0.066)$. The variation in canavalia biomass production within GR and PT sites was higher than the variation between sites.

\section{$\mathrm{N}$ budgets}

The components of the soil surface $\mathrm{N}$ budget and the resulting balance for each treatment on each site are presented in Table 3. Nitrogen input from mineral fertilizers applied to maize was from 38 to $68 \mathrm{~kg} \mathrm{~N} \mathrm{ha}^{-1}$. Mineral fertilizers and seeds contributed per site equally to $\mathrm{M} / \mathrm{B}$ and $\mathrm{M} / \mathrm{C}$ rotation. In relation to the overall $\mathrm{N}$ inputs, $\mathrm{Nfert}$ represented on average for both years $88 \%$ of the total $\mathrm{N}$ input in the $\mathrm{M} / \mathrm{B}$ rotation, and $69 \%$ in the $\mathrm{M} / \mathrm{C}$ rotation. For both years, Nseed represented from 3 to $6 \%$ of the total $\mathrm{N}$ input. The contribution of symbiotic $\mathrm{N}_{2}$ fixation to the $\mathrm{M} / \mathrm{B}$ rotation did not exceed $8 \mathrm{~kg} \mathrm{~N} \mathrm{ha}^{-1}$ (8 and $3 \%$ of the total $\mathrm{N}$ input in 2007 and 2008, respectively), whereas it was on average 22 and $17 \mathrm{~kg} \mathrm{~N} \mathrm{ha}^{-1}$ (or 29 and $24 \%$ of the total $\mathrm{N}$ input) in the $\mathrm{M} / \mathrm{C}$ rotation in 2007 and 2008, respectively. Nitrogen exported through maize harvest ranged from 16 to $67 \mathrm{~kg} \mathrm{~N} \mathrm{ha}^{-1}$. Canavalia represented an export of up to $87 \mathrm{~kg} \mathrm{~N} \mathrm{ha}^{-1}$ in 2007 and $39 \mathrm{~kg} \mathrm{~N} \mathrm{ha}^{-1}$ in 2008 when the whole aboveground biomass was removed.

The M/C0 treatment showed in most cases the highest $\mathrm{N}$ balance per site, with an average surplus of $33 \mathrm{~kg} \mathrm{~N} \mathrm{ha}^{-1}$ in 2007 and $26 \mathrm{~kg} \mathrm{~N} \mathrm{ha}^{-1}$ in 2008 (Fig. 6). In 2007, M/C100 treatments resulted in most cases with a negative $\mathrm{N}$ balance with an average depletion of $15 \mathrm{~kg} \mathrm{~N} \mathrm{ha}^{-1}$. In 2008, the M/C100 balance was in average in equilibrium, with $2 \mathrm{~kg} \mathrm{~N} \mathrm{ha}^{-1}$ in average. An average surplus of 14 and $17 \mathrm{~kg} \mathrm{~N} \mathrm{ha}^{-1}$ in 2007 and 2008, respectively was observed with the $\mathrm{M} / \mathrm{B}$ treatment. The $\mathrm{N}$ balance for both years was influenced by the site $(P=0.015$ in 2007 and $P=0.003$ in 2008). Treatments had a highly significant effect on the $\mathrm{N}$ balance in $2007(P=0.000)$ and a significant effect in $2008(P=0.006)$.

\section{$\mathrm{N}$ recycled}

For the most contrasting treatments $\mathrm{M} / \mathrm{B}$ and $\mathrm{M} / \mathrm{C} 0$, the amount of $\mathrm{N}$ recycled and its source are presented in Fig. 7. After maize harvest, about $18 \mathrm{~kg} \mathrm{~N}^{-1}$ were recycled on the plot with maize residues, independent of the treatment, which represents about 
Table $3 \mathrm{~N}$ budget by site, in $\mathrm{kg} \mathrm{N}^{-1}$, means for each treatment $(n=3)$

\begin{tabular}{|c|c|c|c|c|c|c|c|c|c|c|c|c|}
\hline & \multicolumn{6}{|c|}{$\mathrm{N}$ input } & \multicolumn{6}{|c|}{$\mathrm{N}$ output } \\
\hline & \multirow[t]{2}{*}{ Nfert } & \multicolumn{3}{|l|}{ Nseed } & \multicolumn{2}{|l|}{ Nfix } & \multicolumn{3}{|c|}{ Nexport 2007} & \multicolumn{3}{|c|}{ Nexport 2008} \\
\hline & & Maize & Beans & Canavalia & 2007 & 2008 & $\mathrm{~N}_{\mathrm{M}}$ & $\mathrm{N}_{\mathrm{BG}}$ & $\mathrm{N}_{\mathrm{CBR}}$ & $\mathrm{N}_{\mathrm{M}}$ & $\mathrm{N}_{\mathrm{BG}}$ & $\mathrm{N}_{\mathrm{CBR}}$ \\
\hline \multicolumn{13}{|l|}{$\mathrm{FC}$} \\
\hline $\mathrm{M} / \mathrm{B}$ & 60 & 0.4 & 3.2 & & $1(0)$ & $2(2)$ & 47 (26) & $0(0)$ & & $22(7)$ & $5(7)$ & \\
\hline $\mathrm{M} / \mathrm{C} 0$ & 60 & 0.4 & & 2.5 & $18(10)$ & $11(4)$ & 48 (34) & & $0(0)$ & $23(7)$ & & $0(0)$ \\
\hline M/C50 & 60 & 0.4 & & 2.5 & $21(3)$ & $18(6)$ & $52(7)$ & & $15(2)$ & $23(7)$ & & $12(4)$ \\
\hline $\mathrm{M} / \mathrm{C} 75$ & 60 & 0.4 & & 2.5 & $12(11)$ & $18(2)$ & $63(28)$ & & $14(12)$ & $22(7)$ & & $16(2)$ \\
\hline M/C100 & 60 & 0.4 & & 2.5 & $21(4)$ & $19(6)$ & $67(14)$ & & $31(6)$ & $29(1)$ & & $24(8)$ \\
\hline \multicolumn{13}{|l|}{ GR } \\
\hline $\mathrm{M} / \mathrm{B}$ & 68 & 0.4 & 3.2 & & $7(1)$ & $4(0)$ & 37 (24) & $10(1)$ & & $30(16)$ & $11(1)$ & \\
\hline M/C0 & 68 & 0.4 & & 2.5 & $26(11)$ & $11(2)$ & $38(26)$ & & $0(0)$ & $34(4)$ & & $0(0)$ \\
\hline M/C50 & 68 & 0.4 & & 2.5 & $33(20)$ & $28(6)$ & $58(18)$ & & $25(16)$ & $40(21)$ & & $19(2)$ \\
\hline $\mathrm{M} / \mathrm{C} 75$ & 68 & 0.4 & & 2.5 & $32(27)$ & $21(13)$ & $50(13)$ & & $36(32)$ & $37(20)$ & & $21(12)$ \\
\hline M/C100 & 68 & 0.4 & & 2.5 & $25(17)$ & $10(6)$ & $38(11)$ & & $35(23)$ & $34(25)$ & & $13(7)$ \\
\hline \multicolumn{13}{|l|}{ LP } \\
\hline $\mathrm{M} / \mathrm{B}$ & 38 & 0.4 & 3.2 & & $8(2)$ & $0(0)$ & $55(15)$ & 7 (3) & & 47 (10) & $1(0)$ & \\
\hline $\mathrm{M} / \mathrm{C} 0$ & 38 & 0.4 & & 2.5 & $13(3)$ & $16(6)$ & $57(6)$ & & $0(0)$ & 49 (1) & & $0(0)$ \\
\hline M/C50 & 38 & 0.4 & & 2.5 & $13(4)$ & $14(10)$ & $56(9)$ & & $10(2)$ & 34 (14) & & $10(8)$ \\
\hline M/C75 & 38 & 0.4 & & 2.5 & $13(4)$ & 19 (12) & $56(13)$ & & $15(3)$ & $53(6)$ & & $21(14)$ \\
\hline M/C100 & 38 & 0.4 & & 2.5 & $13(4)$ & $18(3)$ & 59 (13) & & $20(4)$ & $53(16)$ & & $25(6)$ \\
\hline \multicolumn{13}{|l|}{ PT } \\
\hline $\mathrm{M} / \mathrm{B}$ & 38 & 0.4 & 3.2 & & $5(4)$ & $0(0)$ & $28(8)$ & $0(0)$ & & 35 (16) & $0(0)$ & \\
\hline $\mathrm{M} / \mathrm{C} 0$ & 38 & 0.4 & & 2.5 & $18(3)$ & $8(6)$ & $16(11)$ & & $0(0)$ & $47(8)$ & & $0(0)$ \\
\hline $\mathrm{M} / \mathrm{C} 50$ & 38 & 0.4 & & 2.5 & $32(4)$ & $15(0)$ & $44(20)$ & & $34(8)$ & $51(15)$ & & $11(0)$ \\
\hline M/C75 & 38 & 0.4 & & 2.5 & $24(28)$ & 24 (19) & $38(3)$ & & 34 (37) & $51(33)$ & & $26(20)$ \\
\hline M/C100 & 38 & 0.4 & & 2.5 & 42 (18) & $27(0)$ & 37 (22) & & 87 (30) & 49 (12) & & $39(0)$ \\
\hline
\end{tabular}

Standard deviation is given in parenthesis. $M / B$ is the maize-bean rotation; $M / C$ is the maize-canavalia rotation; $N_{M}$ is $\mathrm{N}$ export through maize, i.e. through grains, damaged grains, cobs and husks; $N_{B G}$ is $\mathrm{N}$ export through bean grains; $N_{C B R}$ is $\mathrm{N}$ export through canavalia biomass removed

$32 \%$ of the overall maize $\mathrm{N}$ uptake. Nitrogen recycled in the $\mathrm{M} / \mathrm{C} 0$ rotation is higher than in the $\mathrm{M} / \mathrm{B}$ rotation. Bean residues contributed with about $3 \mathrm{~kg} \mathrm{~N} h a^{-1}$ to the $\mathrm{N}$ recycled. When canavalia was not removed, an average value of $22 \mathrm{~kg} \mathrm{~N} \mathrm{ha}^{-1}$ was recycled on the plot with canavalia biomass.

\section{Discussion}

Symbiotic $\mathrm{N}_{2}$ fixation estimated with the ${ }^{15} \mathrm{~N}$ natural abundance method

The suggested minimum difference of $2 \%$ between reference plants and legumes (Unkovich et al. 1994) was reached at all sites and for both $\mathrm{M} / \mathrm{B}$ and $\mathrm{M} / \mathrm{C}$ treatments (Fig. 4). Standard deviation of all reference species $\delta^{15} \mathrm{~N}$ per site was in average $1.1 \%$, and was not higher than $2.2 \%$, which shows that soil $\delta^{15} \mathrm{~N}$ was relatively homogeneous on each site. For canavalia, the $B$-value obtained was in the range reported for tropical legume species used as forage or cover crops (Unkovich et al. 2008). The value for bean was slightly lower than -2.2 reported for common bean by Unkovich et al. (2008).

Bean \%Ndfa was higher than the average of $36 \%$ reported by Herridge et al. (2008) for common bean in farmers fields. Canavalia \% Ndfa in 2007 was in the range of the $57-69 \%$ reported by Giller (2001) for Canavalia ensiformis. 

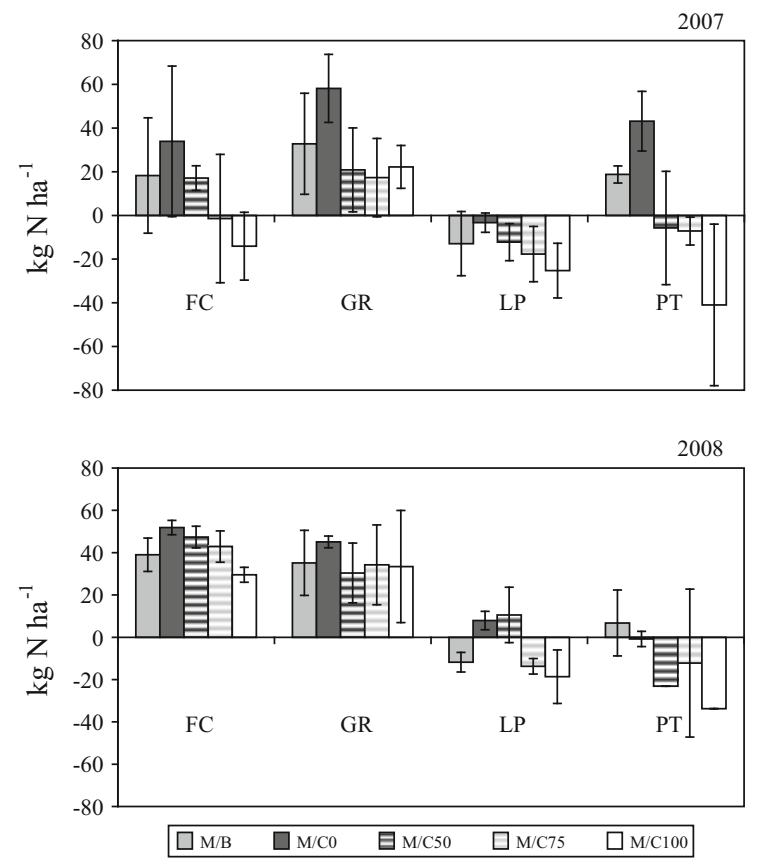

Fig. $6 \mathrm{~N}$ balance for all sites in 2007 and 2008. Error bars represent the standard deviation $(n=3) . M / B$ is the maizebean rotation; $M / C X$ is the maize-canavalia rotation, with different percentages $(X)$ of biomass removed during the dry season

Canavalia had an average \%Ndfa of $64 \%$ in 2007 , despite the fact that it was grown for the first time in this region and not inoculated. For the second year of cultivation of canavalia, an average increase of about $17 \%$ was observed compared to the first year values. Results from the pot study conducted at CIATColombia showed that nodulation is more rapid and abundant (30\% more nodule fresh weight) when canavalia is inoculated with rhizobia from a site where it has been grown for 5 years (S. Douxchamps, unpublished data). Higher $\% \mathrm{Ndfa}$ can therefore be expected after a few years of cultivation, and may reach in the third year the value of $80 \%$ as reported for many tropical green manure legumes (Giller 2001; Thomas et al. 1997).

Parameters of the $\mathrm{N}$ balance and their uncertainties

\section{Effect of legume biomass production on Nfix}

Compared to on-station trials conducted in Brazil, canavalia biomass production was similar to the

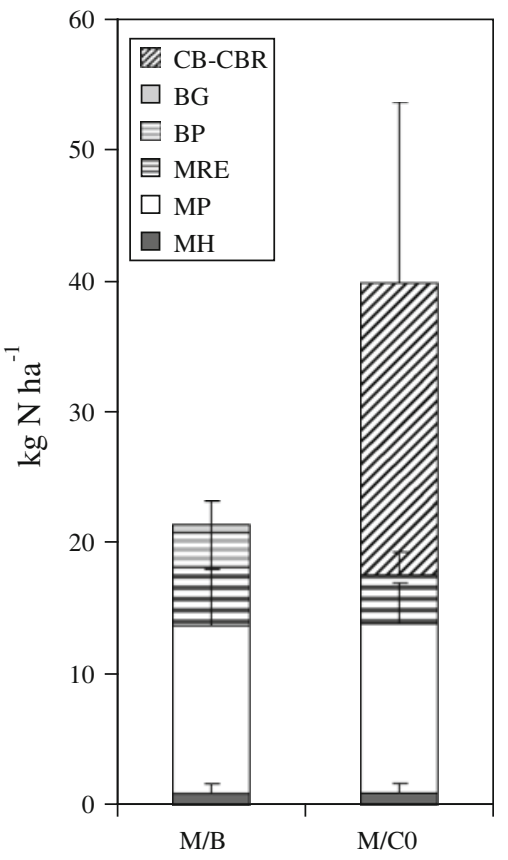

Fig. $7 \mathrm{~N}$ recycled for the most contrasting treatments. Average of 2007 and 2008, for all sites. Error bars are standard deviation $(n=24)$. Origin of the $\mathrm{N}$ recycled is indicated as $C B-C B R$ for canavalia biomass recycled, $B G$ for bean grain, $B P$ for bean plants, $M R E$ for maize ears not harvested, $M P$ for maize plants, $M H$ for maize husks

values of 230 to $6,550 \mathrm{~kg} \mathrm{ha}^{-1}$ observed when grown during the dry season (Burle et al. 1999) but lower than the value of $10,030 \mathrm{~kg} \mathrm{ha}^{-1}$ observed when grown entirely during the rainy season (Carsky et al. 1990). Canavalia biomass production varied highly among plots. The reasons behind this variation are due to soil and topographic factors, which are discussed elsewhere (Douxchamps, 2010). Because biomass production varied more than \%Ndfa, the variation in Nfix was determined by variation in biomass, which has been also observed by Thomas et al. (1997) in the humid tropics for three forage legumes. Likewise, the difference of biomass production between the legumes was the main reason why Nfix by canavalia was on an average about $16 \mathrm{~kg} \mathrm{~N} \mathrm{ha}^{-1}$ higher than that of bean crop.

This difference in Nfix between the two legumes was underestimated, as below-ground biomass contribution was partially taken into account for bean but not for canavalia. Canavalia is known for its deep pivoting root system with lots of fine roots and lateral root extension up to $3.5 \mathrm{~m}$ (Alvarenga et al. 1995). 
Besides the problems encountered in trying to estimate or recover such a root system, the rapid turnover of belowground tissues and root exudation make difficult to determine below-ground $\mathrm{N}$ contributions (Cherr et al. 2006). Below-ground $\mathrm{N}$ associated with or derived from roots can represent up to $50 \%$ of the total plant $\mathrm{N}$ of legumes (Herridge et al. 2008). To account for below-ground N, Unkovich et al. (2008) suggested a multiplication by factor 2 for fodder legumes, which would give for canavalia in our trial an average Nfix of $44 \mathrm{~kg} \mathrm{~N} \mathrm{ha}^{-1}$ in 2007 and $34 \mathrm{~kg} \mathrm{~N} \mathrm{ha}^{-1}$ in 2008 . For bean, only dry roots were recovered, whereas exudates and root turnover were not taken into account. By using the multiplication factor of 1.4 suggested by Unkovich et al. (2008), the maximum Nfix for bean in our trial would be of $11 \mathrm{~kg} \mathrm{~N} \mathrm{ha}^{-1}$.

\section{Effect of on-farm conditions on Nfert, Nseed, and Nexport}

Nfert and Nseed were distributed by hand, by different farmers. Distribution of fertilizer and seed was not as exact as when it is done by machines or in on-station trials. As $\mathrm{N}$ contained in seeds remained small compared to the other factors of the budget, its potential variation had relatively small effect on the $\mathrm{N}$ balance estimations. Likewise, plant density was also somewhat heterogeneous between plots.

The estimation of Nexport by maize was also affected by human factors. For example, people do not enter the fields very carefully: they may drop ears on the ground, or sometimes grab an appetizing maize ear to eat on the way back home. This may be one reason why plants with empty husks were found. The amount of empty husks represented on average $6 \%$ of the good ears.

Therefore, the results from the different sites should not be combined as one single effect of canavalia when introduced on-farm, but rather be seen as a range of possible responses, taking into account farmers practices and their impacts on data variability. One may argue that those conditions render difficult to design a precise nutrient management guidelines for the region. Uncertainties are however part of budget calculations at all scales, and there are various ways to deal with them in the subsequent decision making process (Oenema et al.
2003). As farmers cannot afford taking risks, safety margins have to be taken into account.

\section{Interpretation of the balances}

Both years and on all sites, increasing cutting intensities of canavalia reduced the $\mathrm{N}$ balance. On one hand, canavalia increased $\mathrm{N}$ input into the system compared to $\mathrm{M} / \mathrm{B}$ rotation, but on the other hand it increased soil $\mathrm{N}$ depletion if completely removed. Under $\mathrm{M} / \mathrm{B}$ rotation, balance depended much on bean yields. When beans were harvested, the balance became negative, except in the sites where high amounts of mineral fertilizer were applied (FC and GR). The positive to neutral $\mathrm{N}$ balance on $\mathrm{M} / \mathrm{B}$ is mainly due to the low yields of common bean. Assuming yields of $800 \mathrm{~kg} \mathrm{~N} \mathrm{ha}^{-1}$ (FAO 2009), N export through bean harvest would become about $30 \mathrm{~kg} \mathrm{~N} \mathrm{ha}^{-1}$, which brings the balance estimate to negative in most cases, with an average value of $-6 \mathrm{~kg} \mathrm{~N} \mathrm{ha}^{-1}$ and a maximum value of $-40 \mathrm{~kg} \mathrm{~N} \mathrm{ha}{ }^{-1}$ on LP site. A positive $\mathrm{N}$ balance for the $\mathrm{M} / \mathrm{B}$ rotation does not mean that the system is sustainable: lower bean yields mean lower or no income. Likewise, the observation of a higher $\mathrm{N}$ balance for all treatments of a site is due to reduced $\mathrm{N}$ export by maize. For example, on FC site maize yields were much higher in 2007 than in 2008, and thus the balance resulted much lower. When export through maize grain is not compensated by mineral fertilizers, as on LP and PT sites, the $\mathrm{N}$ balance becomes negative. If we would include the below ground $\mathrm{N}$ contribution from the legumes as presented above, the deficit observed in the M/C100 rotations would be in five of eight cases compensated, with an average balance of $18 \mathrm{~kg} \mathrm{~N}^{-1}$. The impact on $\mathrm{M} / \mathrm{B}$ rotations would be lower, and would not compensate the deficit observed on LP site, which would remain at about $-10 \mathrm{~kg} \mathrm{~N} \mathrm{ha}^{-1}$.

Effect of canavalia on maize yields

Many experiments have demonstrated the positive effect of legumes on succeeding crops (Peoples and Craswell 1992). However, in this study, the integration of canavalia as green manure had no effect on the following maize crop, probably because (1) one year of rotation is not sufficient to observe an effect, (2) the mineral fertilizer background is too high compared to 
the $\mathrm{N}$ input by canavalia, and (3) other factors related to management practices may have limited a productivity increase. For example, MRE, i.e. the amount of ears not harvested, represent a potential maize yield increase if crop management is improved. On all sites and for the 2 years, MRE had a mean value of $350 \mathrm{~kg} \mathrm{ha}^{-1}$, which corresponds to a loss of $10 \%$ of good grain yield. According to farmers, up to $50 \%$ of maize grain yield losses can occur in the region due to this problem and these losses do not include post harvest losses. Before important changes in nutrient management as the introduction of a legume in the rotation, the traditional system could be improved by a few simple efforts. There are opportunities to increase productivity with improved management, e.g., concerning plant density, timing of fertilizer application and weed control.

\section{$\mathrm{N}$ recycled and rotation sequence}

According to the design of the experiment, we expected that in the green manure scenario $\mathrm{M} / \mathrm{C} 0$, the $\mathrm{N}$ of crop residues is recycled within the plot, as no cows would enter the field to graze. However, in practice, according to participatory workshops with farmers, there will probably be only one type of M/C rotation. Farmers will allow cows to graze totally canavalia at the onset of the dry season. Regrowth, which was not expected when the experiment was designed, has been observed during the dry season when plants are not cut down to the ground level i.e., after grazing, and may be used for soil improvement. The former $\mathrm{N}$ recycled would in this case represent the amount of $\mathrm{N}$ available for grazing during the dry season. Rufino et al. (2006) reported for African dairy studies that on average about $80 \%$ of the ingested $\mathrm{N}$ is returned with manure. Assuming the same proportion recycled for cows in our trial and all $\mathrm{N}$ excreted being returned to the grazed plot, $33 \mathrm{~kg} \mathrm{~N} \mathrm{ha}^{-1}$ on average would be recycled through canavalia grazing, under the form of faeces and urine. While the urine fraction would fall on a single spot at high concentration, the faeces fraction can be uniformly distributed on the plot surface by farmers. An efficient animal manure management would therefore be essential to maximize $\mathrm{N}$ recycling and compensate the $\mathrm{N}$ deficit observed with $\mathrm{M} / \mathrm{C} 100$ rotation.

The proposed rotation sequence would therefore be to alternate this most probable $\mathrm{M} / \mathrm{C}$ rotation with the $\mathrm{M} / \mathrm{B}$ rotation: canavalia would grow on the area
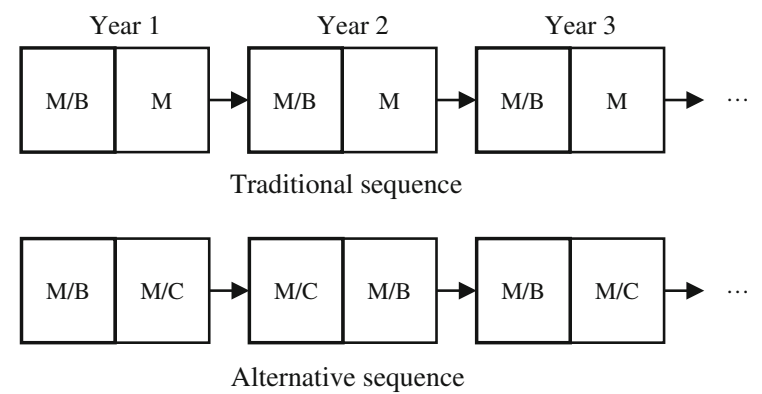

Fig. 8 Traditional rotational sequences on the 2 ha cropping area of a smallholder farm, and proposed alternative sequence including canavalia. Bold area enlightens the rotation succeeding on the same area. $M / B$ is the maize-bean rotation, $M / C$ is the maize-canavalia rotation, $M$ is maize alone

not cultivated by beans (i.e. about 1 ha), and crops would be exchanged the following year, i.e., on the same area the sequence would be M/B-M/C-M/B-M/ $\mathrm{C}$ etc. (Fig. 8). In the traditional sequence, the succession of $\mathrm{M} / \mathrm{B}$ and $\mathrm{M}$ (maize alone) rotations depletes $\mathrm{N}$ stocks over years, moreover on sites with low mineral fertilizer applications. The alternative sequence will build up $\mathrm{N}$ stocks year after year. Moreover, canavalia can reduce erosion and decrease weed pressure. The time until seeing an effect on agricultural productivity depends on the biophysical limitations of each site and the management options chosen by the farmers. Canavalia yield is assumed to be maintained over years. Legume yields can decrease after a few years of cultivation due to pests and diseases, as has been reported in other trials (Bünemann et al. 2004). However, this has not yet been observed with canavalia in a 6-year on-station experiment where canavalia was planted on the same plots every year (A. Schmidt et al., unpublished data). Still, the proposed rotation sequence needs long term testing on-farm. The use of models, once calibrated, can also be useful in predicting the effects of rotation sequences on soil fertility (Walker et al. 2008).

\section{Limitations of the soil surface $\mathrm{N}$ budget approach}

The underlying assumption of a nutrient budget is that of a mass balance i.e. nutrient input to the system minus nutrient outputs from the system equals the change in storage within the system (Meissinger and Randall 1991). However, soil surface budgets consider soil as a black box, and do not provide 
information on the fate or origin of any budget surplus i.e. whether it is lost from the system or stored in the soil (Watson et al. 2002). Due to unaccounted $\mathrm{N}$ losses, like leaching and gaseous losses, $\mathrm{N}$ balances are overestimated unless they would be compensated by atmospheric $\mathrm{N}$ deposition. Accurate data being unavailable for the study region, atmospheric deposition was not included in the budget and assumed to be equal for all farms. Surface lateral nutrient flows, i.e. inputs and outputs by sedimentation, erosion and runoff were also not quantified. Despite the fact that those processes are left out, soil surface budgets based on "easy-tomeasure" flows have proved their utility in providing useful information to farmers and policy makers on soil fertility and on the need for restoration (AduGyamfi et al. 2007; Rego et al. 2003), even in sloping hillsides of the tropics (Briggs and Twomlow 2002). These flows are also the easiest to manipulate to influence the nutrient balances in the short term (Bekunda and Manzi 2003). However, the estimation of lateral nutrient flows and gaseous losses is essential if an extrapolation of $\mathrm{N}$ budgets at landscape level and for a longer time frame is envisaged (Smaling et al. 1993). Finally, to predict how much $\mathrm{N}$ can be expected from the use of canavalia over years, an in-depth study on soil $\mathrm{N}$ fluxes is needed, including a determination of the fertilizer value of manure from cows fed with canavalia, an evaluation of $\mathrm{N}$ losses and of the belowground contribution of the legumes, and an assessment of the $\mathrm{N}$ mineralization rate for the different soil types of the Nicaraguan hillsides.

\section{Conclusions}

When used as green manure, canavalia represents a net $\mathrm{N}$ input into the crop rotation due to symbiotic $\mathrm{N}$ fixation. Still, mineral fertilizers are necessary to maintain the $\mathrm{N}$ balance positive. Using canavalia as forage depletes soil $\mathrm{N}$, and should be compensated by an effective return of animal manure on the plots. The introduction of canavalia in the Nicaraguan hillsides has the potential to improve agricultural production. However, the time needed to visualize an effect on crop productivity depends on the biophysical limitations of each site and the management done by the farmers.
Acknowledgments We warmly thank Don Felipe Calderón, Don Gabriel Ruiz, Don Lorenzo Peralta and Don Pedro Torres, the four farmers of Santa Teresa who participated in this study. We also gratefully acknowledge fieldwork assistance by Alexander Benavidez (INTA) and Noémi Uehlinger (ETH), as well as samples preparation by Elbis Chavarria and Gonzalo Borrero (CIAT). We thank two anonymous reviewers as well as Prof. Dr. Georg Cadisch (University of Hohenheim, Germany) for useful comments on an earlier version of the manuscript. Financial support was provided by the NorthSouth Center of ETH Zurich.

\section{References}

Adu-Gyamfi JJ, Myaka FA, Sakala WD, Odgaard R, Vesterager JM, Hogh-Jensen H (2007) Biological nitrogen fixation and nitrogen and phosphorus budgets in farmermanaged intercrops of maize-pigeonpea in semi-arid southern and eastern Africa. Plant Soil 295:127-136

Alvarenga RC, da Costa LM, Moura Filho W, Regazzi AJ (1995) Potential of some green manure cover crops for conservation and recuperation of tropical soils. Pesqui Agropecu Bras 30:175-185

Ayarza M, Amezquita E, Rao I, Barrios E, Rondon M, Rubiano Y, Quintero M (2007) Advances in improving agricultural profitability and overcoming land degradation in savanna and hillside agroecosystems of tropical America. In: Bationo A, Waswa B, Kihara J, Kimetu J (eds) Advances in integrated soil fertility management in sub-saharan africa: challenges and opportunities. Springer, Dordrecht, pp 209-229

Bekunda M, Manzi G (2003) Use of the partial nutrient budget as an indicator of nutrient depletion in the highlands of southwestern Uganda. Nutr Cycl Agroecosyst 67:187-195

Bindraban PS, Stoorvogel JJ, Jansen DM, Vlaming J, Groot JJR (2000) Land quality indicators for sustainable land management: proposed method for yield gap and soil nutrient balance. Agric Ecosyst Environ 81:103-112

Boddey RM, De Moraes Sa JC, Alves BJR, Urquiaga S (1997) The contribution of biological nitrogen fixation for sustainable agricultural systems in the tropics. Soil Biol Biochem 29:787-799

Boddey RM, Peoples MB, Palmer B, Dart PJ (2000) Use of the $15 \mathrm{~N}$ natural abundance technique to quantify biological nitrogen fixation by woody perennials. Nutr Cycl Agroecosyst 57:235-270

Bordin L, Farinelli R, Penariol FG, Fornasieri Filho D (2003) Double crop - Common bean with upland rice, submitted to rates of nitrogen fertilization after green cover under no-tillage system. Bragantia 62:417-428

Briggs L, Twomlow SJ (2002) Organic material flows within a smallholder highland farming system of South West Uganda. Agric Ecosyst Environ 89:191-212

Bünemann EK, Smithson PC, Jama B, Frossard E, Oberson A (2004) Maize productivity and nutrient dynamics in maize-fallow rotations in western Kenya. Plant Soil 264:195-208

Burle ML, Lathwell DJ, Suhet AR, Bouldin DR, Bowen WT, Resck DVS (1999) Legume survival during the dry season 
and its effect on the succeeding maize yield in acid savannah tropical soils. Trop Agricul 76:217-221

Carsky RJ, Reid WS, Suhet AR, Lathwell DJ (1990) Screening legume green manures as nitrogen-sources to succeeding non-legume crops: 3 . The buried bag method. Plant Soil 128:275-282

Cherr CM, Scholberg JMS, McSorley R (2006) Green manure approaches to crop production: a synthesis. Agronomy $\mathrm{J}$ 98:302-319

CIAT (2004) Annual report 2004. Tropical grasses and legumes (IP5). Optimizing genetic diversity for multipurpose use, Cali, Colombia. 217 p

de Carvalho AM, Bustamante MMD, Sousa JGA, Vivaldi LJ (2008) Decomposition of plant residues in latosol under corn crop and cover crops. Rev Bras Cienc Solo 32:28312838

Douxchamps S (2010) Integration of Canavalia brasiliensis in the crop-livestock system of the Nicaraguan hillsides: environmental adaptation and nitrogen dynamics. $\mathrm{PhD}$ thesis No 18859, ETH Zürich, Switzerland

FAO (2009) http://faostat.fao.org/

Giller KE (2001) Nitrogen fixation in tropical cropping systems. CABI, Wallingford, $423 \mathrm{p}$

Haydock KP, Shaw NH (1975) The comparative yield method for estimating dry matter yield of pasture. Aust J Exp Agric Animal Husb 15:663-670

Herridge DF, Peoples MB, Boddey RM (2008) Global inputs of biological nitrogen fixation in agricultural systems. Plant Soil 311:1-18

Hogberg P, Nasholm T, Hogbom L, Stahl L (1994) Use of $15 \mathrm{~N}$ labeling and $15 \mathrm{~N}$ natural-abundance to quantify the role of mycorrhizas in $\mathrm{N}$-uptake by plants - Importance of seed-N and of changes in the $15 \mathrm{~N}$ labeling of availableN. New Phytol 127:515-519

IFAD (2009) http://www.ruralpovertyportal.org/web/guest/ country/statistics/tags/nicaragua

INETER (2009) http://www.ineter.gob.ni/Direcciones/meteo rologia/

Krom MD (1980) Spectrophotometric determination of ammonia - a study of a modified Berthelot reaction using salicylate and dichloroisocyanurate. Analyst 105:305-316

MAGFOR (2008) Municipio de Condega-Subgrupos Taxonómicos. Ministerio Agropecuario y Forestal, Managua

Meissinger JJ, Randall GW (1991) Estimating nitrogen budgets for soil-crop systems. In: Follett RF, Keeney DR, Cruse RM (eds) Managing nitrogen for groundwater quality and farm profitability. SSSA Madison, Wisconsin, pp 85-124

Nelson DW, Sommers LE (1982) Total carbon, organic carbon and organic matter. Methods of soil analysis. American Society of Agronomy, Madison

Oberson A, Nanzer S, Bosshard C, Dubois D, Mader P, Frossard E (2007) Symbiotic N-2 fixation by soybean in organic and conventional cropping systems estimated by $\mathrm{N}-15$ dilution and N-15 natural abundance. Plant Soil 290:69-83

Oenema O, Kros H, de Vries W (2003) Approaches and uncertainties in nutrient budgets: implications for nutrient management and environmental policies. Euro J Agronomy 20:3-16

Ojiem JO, Vanlauwe B, de Ridder N, Giller KE (2007) Nichebased assessment of contributions of legumes to the nitrogen economy of Western Kenya smallholder farms. Plant Soil 292:119-135

Peel MC, Finlayson BL, McMahon TA (2007) Updated world map of the Koppen-Geiger climate classification. Hydrol Earth Syst Sci 11:1633-1644

Peoples MB, Craswell ET (1992) Biological nitrogen-fixation-investments, expectations and actual contributions to agriculture. Plant Soil 141:13-39

Pfister F (2003) Resource potentials and limitations of a Nicaraguan agricultural region. Swiss Federal Institute of Technology, Zurich, p 139

Pinheiro JC, Bates DM (2000) Mixed-effects models in S and S-PLUS. Springer, Berlin

R Development Core Team (2007) R: a language and environment for statistical computing. R Foundation for Statistical Computing, Vienna

Rego TJ, Rao VN, Seeling B, Pardhasaradhi G, Rao J (2003) Nutrient balances - a guide to improving sorghum- and groundnut-based dryland cropping systems in semi-arid tropical India. Field Crops Res 81:53-68

Rufino MC, Rowe EC, Delve RJ, Giller KE (2006) Nitrogen cycling efficiencies through resource-poor African croplivestock systems. Agric Ecosyst Environ 112:261-282

Rufino MC, Tittonell P, Reidsma P, López-Ridaura S, Hengsdijk H, Giller KE, Verhagen A (2009) Network analysis of $\mathrm{N}$ flows and food self-sufficiency - a comparative study of crop-livestock systems of the highlands of East and southern Africa. Nutr Cycl Agroecosyst 85:169-186

Said AN, Tolera A (1993) The supplementary value of forage legume hays in sheep feeding - Feed-intake, nitrogenretention and body-weight change. Livest Prod Sci 33:229-237

Schloen M, Peters M, Schultze-Kraft R (2005) Canavalia brasiliensis Mart. ex Benth

Schmidt A, Peters M, Franco L H and Schultze-Kraft R (2005) Canavalia brasiliensis-a multipurpose legume for the sub-humid tropics. In: Mara FPO', Wilkins RJ, 't Mannetje L, Lovett DK, RPAM, Boland TM (eds) XX international grassland congress: offered papers, Wageningen Academic Publishers, pp 382

Shearer G, Kohl DH (1986) N2 fixation in field settings: estimations based on natural abundance. Aust J Plant Physiol 13:699-744

Smaling EMA, Stoorvogel JJ, Windmeijer PN (1993) Calculating soil nutrient balances in Africa at different scales.2. District Scale. Fert Res 35:237-250

Smyth J, Ayarza MA, Brizuela L, Orozco PP (2004) Testing diagnosis of the NuMaSS expert system for $\mathrm{N}$ and $\mathrm{P}$ applications in corn-based systems (eds) Integrated soil fertility management in the tropics. TSBF annual report 2004, CIAT, Cali, Colombia

Tan ZX, Lal R, Wiebe KD (2005) Global soil nutrient depletion and yield reduction. J Sustain Agric 26:123-146

Thomas RJ, Asakawa NM, Rondon MA, Alarcon HF (1997) Nitrogen fixation by three tropical forage legumes in an acid-soil savanna of Colombia. Soil Biol Biochem 29:801-808

Tiessen H, Moir J (1993) Characterisation of available P by sequential extraction. In: Carter MR (ed) Soil sampling and methods of analysis. CRC Press Inc, Boca Raton, pp 75-86 
Unkovich MJ, Pate JS, Sanford P, Armstrong EL (1994) Potential precision of the $\mathrm{d} 15 \mathrm{~N}$ natural abundance method in the field estimates of nitrogen fixation by crop and pasture legumes in south-west Australia. Aust J Agric Res 45:119-132

Unkovich MJ, Herridge DF, Peoples MB, Cadisch G, Boddey RM, Giller KE, Alves B, Chalk PM (2008) Measuring plant-associated nitrogen fixation in agricultural systems. ACIAR Monograph No. 136, 258 pp

Vanlauwe B, Giller KE (2006) Popular myths around soil fertility management in sub-Saharan Africa. Agric Ecosyst Environ 116:34-46
Walker AP, van Noordwijk M, Cadisch G (2008) Modelling of planted legume fallows in Western Kenya. (II) productivity and sustainability of simulated management strategies. Agrofor Syst 74:143-154

Watson CA, Bengtsson H, Ebbesvik M, Loes AK, Myrbeck A, Salomon E, Schroder J, Stockdale EA (2002) A review of farm-scale nutrient budgets for organic farms as a tool for management of soil fertility. Soil Use Manag 18:264-273

Zingore S, Murwira HK, Delve RJ, Giller KE (2007) Influence of nutrient management strategies on variability of soil fertility, crop yields and nutrient balances on smallholder farms in Zimbabwe. Agric Ecosyst Environ 119:112-126 